\title{
СОЦІОКУЛЬТУРНЕ РЕГУЛЮВАННЯ ТРАНСФОРМАЦІЙНИХ ПРОЦЕСІВ В СУЧАСНОМУ СУСПІЛЬСТВІ
}

\section{В.Ф. Капіца}

Сучасні суспільні системи, що інтенсивно трансформуються і набувають ознак постіндустріальних та інформаційних суспільств, потребують нового підходу до регулювання складних соціальних процесів. Більшість сучасних концепцій інформаційного суспільства як соціальної системи постіндустріального типу грунтуються в основному на техногенних підвалинах без врахування соціокультурного аспекту. Такі підходи найчастіше розглядають інформаційне суспільство у вигляді суспільства масових комунікацій та комп'ютерних технологій. Подібне технологізоване інформаційне суспільство все більше перетворюється на «суспільство без цінностей». Замість реальних ціннісних систем, встановлюються їх формальні ієрархії за критеріями престижності і символічної статусності.

Такий підхід до розуміння цінностей практично виключає духовність та творчі начала людини і тим самим унеможливлює розуміння людини як головної суспільної цінності. Натомість функціонують цінності-«симулякри», позбавлені реальних смислів і значень. Дослідники сучасних соціальних процесів фіксують прихід «суперсимволічної економіки», котра змінює саму систему створення матеріальних та духовно-інформаційних цінностей. При цьому первинною соціально-економічною компонентою суспільства стає знання [6, с. 48], що перетворюється на капітал, як інтелектуальний, так і соціальний. Послаблюється необхідність у сирому, недоробленому матеріалі - знання стає головним джерелом розвитку економіки.

Актуальні проблеми духовності: 
На цій основі формується суспільне виробництво зі специфічними інформаційними потребами в сфері організації управління соціальними системами. Головна інформаційна потреба - це управління інформацією через людські комунікації [7, с.33-34]. Головне завдання подібних комунікативних процесів - не тільки ефективний обмін інформацією, а «забезпечення розуміння інформації в міжособистісному спілкуванні, подолання семантичних бар'єрів між суб'єктами» [3, c. 171-177].

У ході соціально-трансформаційних процесів інформаційне суспільство все більше потребує «ціннісного управління» 3 широкими можливостями для творчої самореалізації суб'єктів. Головним завданням подібної ціннісної регуляції є створення умов вільного професійного вибору суб'єктом свого «кластера знань» за творчими здібностями. Для досягнення економічної ефективності подібного управління вже соціокультурного, а не технократичного типу, необхідно створити відповідно розвинуті культуросферу та інфосферу суспільного виробництва і самого суспільства.

Соціокультурне регулювання трансформаційних процесів в сучасному суспільстві перш за все повинно бути зорієнтовано на зміну самої парадигми суспільного спілкування. Подібна трансформаційна зміна представлена переходом від суб'єктоцентрованого розуму на парадигму взаєморозуміння як «парадигму інтерсуб'єктивного зв'язку комунікативно-соціалізованих та взаємовизнаних індивідів» $[9$, с. 292293]. У такому контексті спілкування набуває особливої «процедурної раціональності», в ньому спостерігається рівноправний зв'язок різних форм орієнтації [9, с. 306].

Інноваційні розробки в цьому напрямку свідчать, що система сучасного суспільного управління потребує наявності спеціальних соціокультурних «комунікативних кластерів», тобто тих точок перетину, які забезпечать взаємопорозуміння учасників дискурсу. Перш за все це «фразеологічні кластери» взаєморозуміння і досягнення взаємної позитивної поведінки інтерсуб'єктів [4, с.58-59]. Такий підхід дозволить сформувати культурно-інформаційний дискурс в суспільній управлінській системі та відповідну інформаційну культуру управління суспільством і його трансформаційними процесами.

Дискурсивний механізм суспільного спілкування, котрий можна регулювати на основі комунікативного дискурсу представлений в таких його головних чинниках $[2$, с. 218$]$.

1. Налагодження комунікативно-інформаційного обміну в суспіль- 
стві: цінностями, смислами, значеннями, досвідом (включаючи суспільний і особистісний комунікативний досвід), практичним значенням, когнітивними практиками, формами і способами творчої самореалізаціі. Їх загальна спрямованість $є$ такою, що лінійно-логічний раціоналізовано-аналітичний дискурс змінюється на нелінійний ціннісно-смисловий, полікультурний.

2. 3 іншого боку, відбувається соціокультурна трансформація комунікативного дискурсу у вигляді підвищення «комунікативної раціональності» суспільства в напрямку його перетворення на інтелектуальне суспільство. За М.Фуко, це зміни і трансформації в мовних структурах суспільства в напрямку їх комунікативної інтелектуалізації та раціоналізації [8, с. 259-276].

Подібний культурний синтез інформації може здійснити така управлінська система, що володіє релевантним культурно-інформаційним світоглядом. Його матеріально-предметну основу утворюють такі культурно-інформаційні предикати [1, с.89]:

- відносини інформаційного випередження і прогнозування;

- відносини інформаційного програмування, котре передбачає наявність програмних продуктів і відповідних баз знань;

- відносини інформаційної експансії або розширеного інформаційного відтворення і функціонування інформаційного капіталу (людського і соціального);

- відносини інформаційного партнерства та інформаційної кон'юнктури, що забезпечують високий рівень конкурентноздатності і надають інформації статус капіталу за відомою схемою «інформація є капітал»;

- інформаційно-підтримуючі відносини, що дозволяють функціонувати суспільству і суспільному виробництву як єдиної і відкритої системи;

- культурно-інформаційні відносини, на базі яких розвивається інформаційна культура суспільства, інформаційна сфера суспільної управлінської культури трансформованого інформаційного суспільства. 
В системі суспільного виробництва управлінський формат інформаційних відносин вибудовується у вигляді макрозв'язків загальносуспільного масштабу. Всі вищеназвані стосунки переносяться на рівень техноструктури великих і надвеликих господарських організацій. При цьому відбувається специфічне поєднання культури та інформаційних технологій, що породжує ряд нових відносин:

- відносини соціоінформаційної самоорганізації і соціокультурної інтеграції;

- відносини культурно-інформаційної самореалізації креативного опредмечення когнітивних практик;

- відносини інформаційної самоосвіти або росту професійної кваліфікації в інформаційній сфері суспільних і господарських відносин;

- інформаційно-моделюючі відносини, що дозволяють розвивати і удосконалювати соціокультурну структуру суспільного виробництва;

- відносини інтелектуальної підтримки, що дозволяють акумулювати інформаційний капітал і трансформувати його в загальносуспільні інтелектуальні активи;

- віртуально-творчі відносини, які розвиваються в рамках «креативного менеджменту» в модусі управлінських інновацій і дозволяють створювати творчі асоціації (групи, співтовариства) неформального лідерства з однорідними статусами (генератори ідей, антрепренери, координатори проектів, новатори впровадження, контролери якості, менеджери-наставники по передачі знань тощо);

- відносини інформаційної самореалізації, що дозволяють трансформувати «інформаційну віртуальність» в інформаційну предметність.

Безпосередньо комунікативні зв'язки, що виникають з комунікативних дій, опосередковуються суспільними відносинами, але вже в якості культурних універсалій зі смислами і значеннями, що мають, за Н. Смелзером, універсальне застосування [5, с. 45-46]. Найчастіше комунікативні зв'язки постають як конкретні різновиди певних переконань та громадських дій, породжених волею громадян до існування 
у відкритому демократичному громадському суспільстві. Таким чином відбувається перетворення людської спільноти із цілковитої єдності людських волінь в соціальне об'єднання, а останнього в громадянську спільноту $[7,10]$. Головне завдання подібного соціокультурного регулювання - розвиток культурно-інформаційних засад формування громадянської культури суспільства в його здатності до самовпорядкування і саморегуляції своєї життєдіяльності.

\section{1 Бібліографія}

[1] Капица В.Ф., Макаров О. И. Корпоративная культура управлення в Больших хозяйственных организациях. - Кривой Рог: Минерал, 2003.

[2] Капица В.Ф., Цыгуль О.В. Философско-методологические основания культурно-информационной общественной системи. - Кривой Рог: Минерал, 2006.

[3] Маскон M.Х., Альберт М., Хедоури Ф. Основи менеджмента.М.: Дело, 1992.

[4] Осовсъка Г.В. Комунікації в менеджменті. - К.: Кондор, 2003.

[5] Смелзер Н. Социология. - М.: Феникс, 1998.

[6] Тоффлер A. Метаморфоза власти. Знание, богатство и сила на пороге XXI века. - М.: АCT, 2001.

[7] Тъоніс Ф. Спільнота і суспільство. - К.: Дух і літера, 2005.

[8] Фуко М. Археологія знання.-К.: Основи, 2003.

[9] Хабермас Ю. Філософський дискурс модерну. - К.: Четверта хвиля, 2001.

[10] Luhman N. Ökologishe Kommunikation.-Oplanden, 1986. 